back to this life. Buddha comforts the porter by telling him that those who had gone to another world will not return in " the body" to this world.

R. Morris.

\title{
4. The Beginnings of Persian History.
}

\author{
Athenceum Club, S.W., \\ Feb. 15, 1892.
}

SrR,-The publication of another volume of the "Records of the Past" is a welcome incident for those students who like to unravel the intricacies of early history, and have not the advantage of being able to read the Egyptian and Assyrian records in the original. Perhaps you will allow me to comment on some problems which have suggested themselves in reading the inseriptions referring to Cyrus published in Prof. Sayce's new volume.

Cyrus calls himself in his own inscriptions King of Ansan or Anzan, and the same title is given to him in the inscription of Nabonidus from Sippara. The name Ansan has given rise to a sharp polemic-Oppert, Winckler, and Nöldeke denying, and Rawlinson, Sayce, Halévy, and others affirming, that it means simply Elam, which itself means The Highlands. It seems to me that the latter view is established beyond all doubt, and Prof. Sayce's arguments are conclusive. Among them is a quotation from a lexical tablet, published in the second volume of The Inscriptions of Western Asia (xlvii. 18), in which Ansan is distinctly given as the equivalent of Elam.

That Cyrus should style himself King of Elam was a startling revelation to some people, and yet it was not so strange after all. The Elamites ${ }^{1}$ or "mountaineers" styled themselves, as we learn from the second column in the Achaemenian inscriptions, Hapirdi. This was converted by

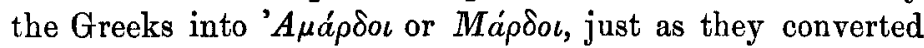
the Persian Bardhiya and the Babylonian Burziya into

1 The Semites so called them, whence their Greek name of Elymeans. 
$\sum \mu \mu^{\prime} \rho \delta \iota s$ or $M M^{\prime} \rho \delta \iota s$, both names meaning simply the Mard or Bard. The native name of the Elamites, therefore, was the Bards or Mards (see Halévy, Babylonian Record, iv. 76).

Now, Ctesias, among his many blundering statements, distinctly calls Cyrus the son of a Mardian robber; and Herodotus and others had already told us that he called his eldest son M'́e $\rho \iota s$ or the Mard, while he repeatedly tells us that Susa was the capital of the Achaemenian kings. There were ample reasons, therefore, for suspecting a close connexion between Cyrus and Elam.

The fact that he should call himself King of Ansan was, nevertheless, remarkable. That he and his people were Persians there can be no doubt whatever; and Darius, who claims to descend from the same stock, styles himself distinctly an Aryan and a Persian. On the other hand, the Elamites or Mards were neither Persians nor Aryans. Their language and their race were not even Indo-European. It follows that Elam must at some date have been conquered by the Persians, whose king then took the name of King of Ansan or Elam. This seems clear. When, then, did this conquest take place? Cyrus in his cylinder inscription calls himself the son of Cambyses the great king, the king of the city of Ansan; the grandson of Cyrus the great king, king of the city of Ansan; and grandson of Tsaispis the great king, king of the city of Ansan (see his Cylinder Inscriptions, 1. 21).

This inscription seems to establish two facts: first, the trustworthiness of the descent of Cyrus and Darius as given by Herodotus, with which it completely agrees; and the worthlessness of the statements of Ctesias on the same subject, when he calls Cyrus the son of Athadates, a Mardian brigand, and Argosti, a goat-herd. In the second place, it points to the fact that the Persian conquest of Ansan or Elam took place at least as early as the time of Tsaispis, or Teispes, as Herodotus calls him; and it seems very probable that Tsaispis was the first Persian leader who occupied it. This was suggested by E. Meyer in his Geschichte des Alterthums, and supported by an ingenious argument which does not 
seem to have been noticed by English writers, although it throws an interesting light on the prophecies of Jeremiah and Ezekiel.

Jeremiah, prophesying at the beginning of the reign of Jehoiakin, i.e. about 604 B.c., still recognizes kings of Elam (c. xxv., v. 25). Prophesying again, at the beginning of the reign of Zedekiah, i.e. about 596, he writes:

"The word of the Lord that came to Jeremiah the prophet concerning Elam in the beginning of the reign of Zedekiah, king of Judah, saying, Thus saith the Lord of hosts : Behold, I will break the bow of Elam, the chief of their might. And upon Elam will I bring the four winds from the four quarters of heaven, and will scatter them toward all those winds; and there shall be no nation whither the outcasts of Elam shall not come; and I will cause Elam to be dismayed before their enemies, and before them that seek their life; and $I$ will bring evil upon them, even my fierce anger, saith the Lord; and I will send the sword after them, till I have consumed them; and I will set my throne in Elam, and will destroy from thence king and princes, saith the Lord. But it shall come to pass in the latter days, that I will bring again the captivity of Elam, saith the Lord" (Jeremiah xlix. 34-39).

A few years later, namely, in the twelfth year after Jehoiakin had been carried away, i.e. in 586 B.c., we find Ezekiel writing:

"The strong among the mighty shall speak to him out of the midst of hell with them that help him, they are gone down, they lie uncircumcised, slain by the sword. Asshur is there. . . There is Elam and all her multitude round about her grave, all of them slain, fallen by the sword, which are gone down uncircumcised into the nether parts of the earth, which caused their terror in the land of the living; yet they have borne their shame with them that go down to the pit. They have set her a bed in the midst of the slain with all her multitude; her graves are round about him, all of them uncircumcised, slain by the sword; though their terror was caused in the land of the living, yet have they borne their 
shame with them that go down to the pit; he is put in the midst of them that be slain" (Jeremiah xxxii. 24, 25).

These passages have been understood to refer to the campaigns of Assurbanipal against Elam; but this is impossible. Assurbanipal had then been dead some time. His reign extended from 668 to 626 ; nor did he destroy the kingdom as is implied in the prophecies. They evidently, as Meyer urges, contemplated the annihilation of the nation, which only followed on its conquest by the Persians; and this probably took place about 596 в.c.

Having approximately fixed the date of the conquest of Elam, the next point that suggests itself for inquiry is, whence did the invading Persians come? This question involves difficulties, and is perhaps fruitful of some suggestions which I will reserve for another letter.

\section{H. H. Howorth.}

5. The Hundred and Tenth Psalm.

Oriental MSS. Department, British Museum, Feb. 14, 1892.

Sir,-While reflecting on the date of Psalm cx. with the Hebrew text before me, it struck me that the psalm contains an acrostic, and that the name embodied in it is no other than that of Simon, Hebrew the first letter in the word בע, which begins the oracle in v. 1; and the headings of the next three verses-

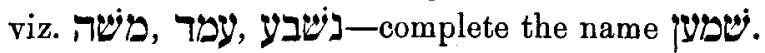

If this be so, the theory (lately advocated with so much force by Prof. Cheyne in his Bampton Lectures) that Simon the Maccabee was the person originally addressed in Psalm cx. would appear to receive a striking confirmation from an entirely unexpected quarter. After the introductory phrase, "The oracle of Yahweh to my lord," the psalmist, bearing the name of his lord vividly in mind, proceeds to weave that name, by means of an acrostic, into the divine oracle itself; and one almost 